\title{
INDONESIAN GENDER-SPECIFIC NEOLOGISMS
}

\author{
Barli Bram $^{1} \quad$ Truly Almendo Pasaribu ${ }^{2}$ \\ Sanata Dharma University, Indonesia ${ }^{12}$ \\ barli@usd.ac.id ${ }^{1}$; trulyalmendo@usd.ac.id²
}

\begin{abstract}
This paper aims at analyzing how gender-specific neologisms in Indonesian are formed and how they conceptualize gender in the community. In this study, neologisms containing gender marked features from online media are extracted. They are classified based on the forms and the word-formation processes. The researchers conduct a careful examination of how the semantic components in the neologisms conceptualize gender in society. The researchers categorized the word-formation processes of gender marked neologisms, consisting of 92 data samples, into seven word-formation processes, starting from the least up to the most frequent processes, namely metaphor, reverse, acronym, diminutive, initialism, borrowing, and blend/clipping compound. The results showed that blends or clipping compounds were formed from English, Indonesian and local languages, such as Javanese, as in the English-Indonesian bohay ('body' and aduhay 'sexy') to refer to a 'sexy female body'. These new words semantically ground on social dimensions carrying several attributes, namely emotional, financial, physical, and sexual. Instead of serving as an act of empowerment, some neologisms, as argued in the findings, reflect negative stigma to females, males, and LGBTQ (lesbian, gay, bisexual, transgender, and queer).
\end{abstract}

Keywords: gender, neologism, slang, stereotype

\begin{abstract}
Abstrak
Makalah ini menganalisis bagaimana gender spesifik neologism dalam bahasa Indonesia terbentuk dan bagaimana kata-kata baru tersebut mengonseptualisasikan gender. Objek penelitian in adalah neologisme yang mengandung fitur gender yang dikumpulkan dari media online. Kata-kata hasil neologisme, atau pembentukan kata baru, diklasifikasikan berdasarkan bentuk dan proses pembentukan katanya. Data dari media online dianalisis dari proses pembentukan katanya dan fitur semantiknya. Data yang terdiri dari 92 sampel diklasifikasikan menjadi tujuh proses pembentukan kata, yaitu metafora, pembalikan, akronim, diminutif, inisialisme, pinjaman, dan campuran/kliping senyawa. Penelitian ini menunjukkan bahwa campuran atau kliping senyawa dibentuk dari bahasa Inggris, bahasa Indonesia, dan bahasa lokal, seperti bahasa Jawa. Contohnya adalah bohay (dari body 'tubuh' dan aduhay 'seksi') untuk merujuk pada 'tubuh wanita seksi'. Kata-kata baru ini dikategorikan secara semantik berdasarkan dimensi sosial yang dengan berbagai jenis atribut, yaitu emosional, finansial, fisik, dan seksual. Alih-alih sebagai alat untuk pemberdayaan, beberapa kata dari proses neologisme dalam temuan kami mencerminkan stigma negatif pada wanita, pria, dan LGBTQ (lesbian, gay, bisexual, transgender, and queer).
\end{abstract}

Kata kunci: gender, neologisme, slang, stereotip 


\section{INTRODUCTION}

Language constantly evolves to better conceptualize social reality or its conception. It dynamically grows by adding new words, which are called neologisms (Min-Chang, 2013). This phenomenon is found in almost all languages, including Indonesian. The use of recent neologisms is widely influenced by mass media. One well-known Indonesian online Instagram account (@ lambeturah) is famous for its catchy new words, such as pelakor, an acronym for perebut lelaki orang or 'man stealer'. Neologisms can be catchy and widely used because it follows certain morphological processes (Fansuri, 2006; Mustofa, 2009; Meehan, 2013). It is noteworthy to observe how the emergence of these words using different language varieties reflects the rich social context of the community.

Indonesians, who are known as heavy users of online social media, are creative in producing new words on an online platform. Indonesia is a country with the fourth largest number of Facebook users in the world, with over 50 million users (Social Bakers, 2012 as cited in Syuhada, \& Gambetta, 2013, p. 447) and the sixth largest number of Twitter users with nearly 30 million users (Bennett, 2012 as cited in Syuhada, \& Gambetta, 2013, p. 447). Indonesians are also known as Internet3 users mostly for social networking purposes (Melissa, Hamidati, Saraswati, \& Flor, 2015, p. 206).

Research on Indonesian neologisms has mainly focused on word-formation processes (Fansuri, 2006; Mustofa, 2009 \& Wijana, 2012). Fansuri (2006) used Cosmopolitan Magazine as the source of data and found that the most common word-formations used in the magazine were conversion and affixation. Mustofa (2009) further elaborated on how technology influenced neologisms from morphology, syntax, and semantic perspectives. Wijana (2012) conducted a study on Indonesian slangs focusing on word formation, linguistic processes, and meaning. One example mentioned in Wijana's (2012) study is the acronym $B M W$, which stands for body mengalahkan wajah 'body defeats face'. He points out how linguistically rich and creative human language is. Although sizable research has problematized neologism from a linguistic point of view, only a few exclusively consider the link between neologisms and gender. It is then crucial not only to analyze the morphological processes of creating these words but also the socialcultural dimension of creating these words.

A great deal of research has shown that the relationship between gender and language is not a direct one (Folse \& Vitanova, 2006; Holmes, 2008), meaning that male and female users do not use language differently because of any biological reasons. However, some studies mention that society constructs gender in different ways which are shown through language and the development of language. Language is believed to be strongly linked to the power of discourse which represents, preserves, or reconstructs social identities as well as practices (Tannen, 1994; Mikic, Mrcela, \& Golob, 2018; Min-Chang, 2013). Language creates power relations between social groups, including gender (Tannen, 1994; Mikic, Mrcela, \& Golob, 2018). A study by Pasaribu \& Effendi (2016) about language use in humor shows that language use tends to carry stereotypes in accord with the expected roles of men and women. The relationship between gender and language is further argued by Martin (2018), who mentions that language use can resist hegemonic power or serve as an act of empowerment.

In this paper we argue that the creation of new words may be influenced by gender. An example is given by Martin (2018) in online media. She mentions that the word pelakor is sexist. It is creatively derived from the phrase perebut lelaki orang or 'man stealer'. However, it positions 
a woman as the one who is guilty, although in an affair it takes two to tango. It conceals information about people's socio-cultural conceptualization. It is important to highlight that the data do not only refer to the binary classification of gender. Some neologisms also acknowledge the existence of the homosexual community. Homosexuality is considered a "deviant" practice by many Indonesians (Martin, 2018). Yet several neologisms reflect the existence of the community and the users' attitude towards the community, which will be discussed in the analysis section. On these notes, we aim at finding out how other neologisms are formed and how they conceptualize gender in the community. With these goals in mind, the data from some Indonesian websites were analyzed using (1) the linguistic theory of word-formation processes and (2) the attribute of the neologisms attached to a gender-specific group.

\section{Neologisms}

Neologisms can be considered as a part of slang as they are often defined in a general sense as an informal style of language. Slangs that emerge through neologisms are formed by combining "old words into new meaning" (Fromkin, et al., 2003, p. 473) such as baper which stands for bawa perasaan. It is used to describe someone who is being sensitive. Some neologisms are totally new words, such as minceu which means 'an administrator'. Fromkin, et al. (2003) also mention that slang also gives new meaning to old words. For example, the word galau has gained a new meaning of 'sad'. This word has been used quite a lot by Indonesian youngsters to express sadness or anxiety. The appearance of neologisms is evident that human beings are creative in introducing and producing new utterances. Some neologisms are evolved from social media to conceptualize cultural development.

Newmark (1988, p. 140) defines neologisms as "newly coined lexical units or existing lexical units that acquire a new sense". Neologisms are useful in identifying new cultural concepts in the development of society. There are several types of neologisms based on the word-formation processes (Yule, 2010, p. 64), namely: coinage, borrowing, compounding, blending, clipping, backformation, conversion, acronym, and derivation. Below are brief elaborations of the wordformation processes in Table 1.

Table 1. Word-formation processes

\begin{tabular}{lll}
\hline $\begin{array}{l}\text { Word-formation } \\
\text { Process }\end{array}$ & Definition & Example \\
\hline Coinage & $\begin{array}{l}\text { Coinage is the formation of } \\
\text { totally new words. }\end{array}$ & $\begin{array}{l}\text { Pepsi is a brand of soda drink. However, it } \\
\text { gains new meaning in the Indonesian } \\
\text { context - it means to urinate. It gains new } \\
\text { words because it shares some similar }\end{array}$ \\
& sounds with the word 'pipis" (to urinate). \\
\hline Borrowing & Borrowing is the process of & $\begin{array}{l}\text { There are many slangy expressions taken } \\
\text { from English (Wijana, 2012), such as kiyut }\end{array}$ \\
& languages. & $\begin{array}{l}\text { which is from an English word 'cut' or } \\
\text { 'sowot' which is originally from the phrase }\end{array}$ \\
& 'so what'. \\
\hline Compounding & Compounding is the process of & A famous example is the combination of \\
& attaching two entirely different & wall and paper into wallpaper.
\end{tabular}

words into one word. 


\begin{tabular}{|c|c|c|}
\hline Blending & $\begin{array}{l}\text { As the name suggests, blending } \\
\text { is a word-formation process } \\
\text { where two or more separate } \\
\text { forms are produced to create a } \\
\text { single new word. }\end{array}$ & $\begin{array}{l}\text { Blending is a process accomplished by } \\
\text { taking some parts of the old words to create } \\
\text { a new word, such as baper. In this case, we } \\
\text { reduce the word bawa (bring) into "ba" as } \\
\text { well as perasaan (feelings) into "per". } \\
\text { These two reduced parts are then combined } \\
\text { into the word baper (moody). }\end{array}$ \\
\hline Clipping & $\begin{array}{l}\text { Clipping occurs when a word } \\
\text { consisting of more than one } \\
\text { syllable is reduced to one } \\
\text { shorter form. }\end{array}$ & $\begin{array}{l}\text { The word kenapa 'why' is clipped into the } \\
\text { word napa; the word tidak is clipped into } \\
\text { the word gak. }\end{array}$ \\
\hline Backformation & $\begin{array}{l}\text { Back-formation is a type of } \\
\text { word formation which reduces } \\
\text { one form into a different word. }\end{array}$ & $\begin{array}{l}\text { Some examples are televise from television, } \\
\text { donate from donation, and hankie from } \\
\text { handkerchief. }\end{array}$ \\
\hline Conversion & $\begin{array}{l}\text { Conversion is a change in the } \\
\text { function of the word. }\end{array}$ & $\begin{array}{l}\text { The word wasap (to send messages through } \\
\text { Whatsapp) is taken from a social media } \\
\text { brand Whatsapp. However, because of its } \\
\text { huge impact on communication, it is often } \\
\text { used as a verb in conversation which means } \\
\text { "to send a text through Whatsapp". }\end{array}$ \\
\hline Initialisms & $\begin{array}{l}\text { Initialisms are formed from the } \\
\text { initial letters of several words. }\end{array}$ & $\begin{array}{l}\text { There are many slangs which are formed } \\
\text { through this word formation, such as LOL } \\
\text { (laugh out loud), GWS (get well soon), and } \\
\text { CMIIW (Correct Me If I'm Wrong). }\end{array}$ \\
\hline
\end{tabular}

Most neologisms are produced based on the formation of lexical building blocks, which might fall into these patterns. The words are the reflection of society. Some examples above show that the new words are tied to social and technical concepts tied in a particular era. With the advent of technology in the $21^{\text {st }}$ century, Indonesian words have the potential to grow even more significantly.

\section{The discourse of gender}

Language is shaped by the speech community and also shapes social relations among the users. Sizable research suggests how language is responsible for constructing social identities and practices. The use of language in a speech community is likely influenced by meanings that create power relations among users (Tannen, 1994; Mikic et.al, 2018). The linguistic phenomenon should not be investigated solely from its linguistic feature, but also through its use within social variables, including gender. Researchers noted that the relationship between language and gender is not direct (Pasaribu, 2017). Male and female users do not use language differently because of any biological reasons. Instead, research mentions that society constructs gender in different ways which are shown through language and the development of language. 


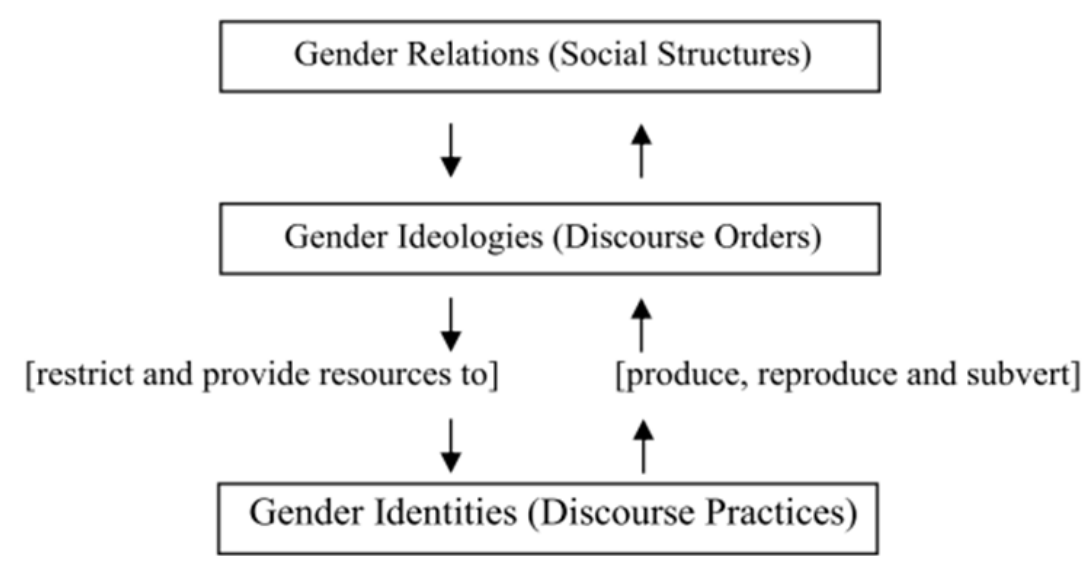

Figure 1. Gender types

Nakamura (2002) shows relations between gender, ideology, and social structures through this graph. Social structures are constructed by language and vice versa. He also further mentions that discourse practice, discourse orders, and social structures are influencing each other. In other words, language has a powerful influence on social change (Litosseliti, 2006). Therefore stereotypes are present in language and changing. Pasaribu (2016) shows how language can be used to preserve the status quo or even supports inequalities, while Martin (2018) elaborates how the use of code-switching challenges government domination or grand narratives of majority.

This research is then concerned with applying, not only linguistic analysis but also users' social concept of gender to investigate gender-marked neologisms. Some words are semantically gender specific which carries gender markers in their features. It is crucial to highlight that the gender markers represented in Indonesian neologisms do not only refer to the gender binary, but some terms refer to homosexuality. Studies suggested that men are representing the cultural norm and women were given the status of liyan or the other. Homosexuals are even more marginalized as it is considered a deviant practice contradicting local values (Martin, 2019). Martin further mentions how a linguistic phenomenon manifesting in code-switching "expand monolithic definitions of Indonesianess". The findings of the data argue how some new words referring to gender, including LGBTQ community, carry both nonjudgemental and also negative connotations reflecting the current cultural norms.

\section{RESEARCH METHOD}

\section{Data Source}

The data were collected from a number of Indonesian social media, blogs, and books related to Indonesian neologisms from May 2018 until October 2018. We scrutinized 92 data qualitatively through verbal means. The figures and numbers in the discussion were presented to support the interpretation of the researchers.

\section{Data Analysis}

This qualitative research aims at answering the following two questions. First, what wordformation processes are found in gender-specific neologisms? Second, what social domains are 
attached to these neologisms? With these goals in mind, content analysis was used. A linguistic theory of word-formation processes was used in analyzing the gender marked neologisms. Furthermore, to analyze the conceptualization of gender and the attribute attached to a genderspecific group, this study interpreted the relationship between the new-formed words and the society based on arguments that words are always understood with respect to domains of experience.

\section{FINDINGS AND DISCUSSION}

\section{Word formation of neologism}

In this section, the researchers resolved the first research question, namely, how the Indonesian online neologisms were formed. Based on the 92 samples collected, the researchers classified them into seven word-formation processes, as presented in Figure 2 below.

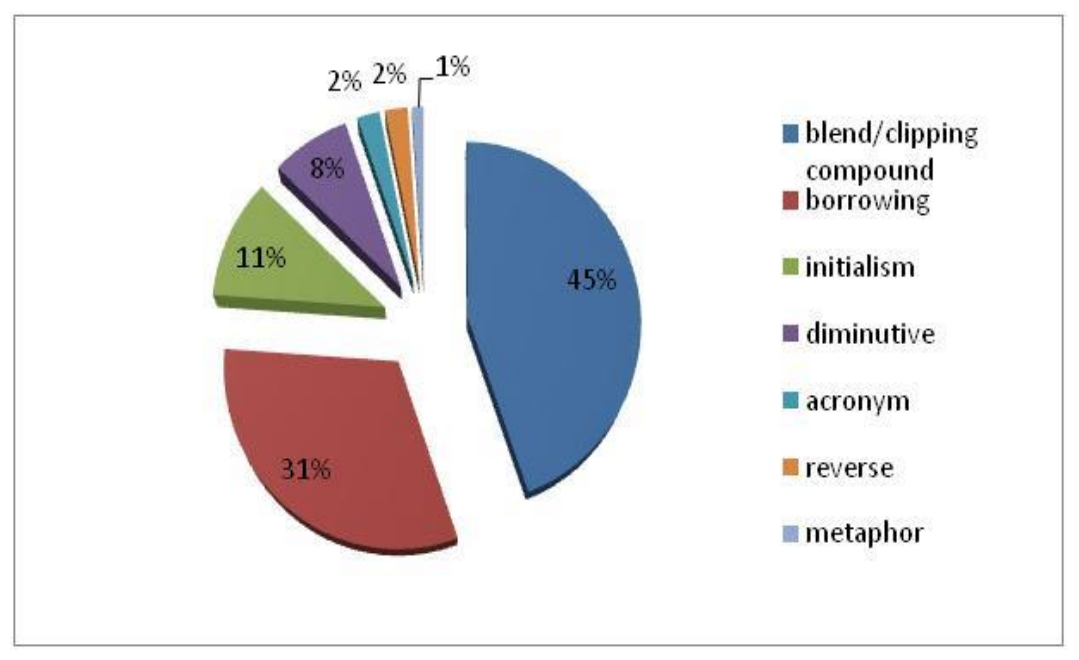

Figure 2. Word formation process frequency

The least productive word-formation process was the so-called metaphor, appearing once only (1\%), through the word jambu (air) or 'water apple', to refer to 'a beautiful girl'. Metaphorically speaking, the word jambu (air) or 'water apple' can be used to describe the qualities of a girl who is beautiful and fresh. Based on the data, the researchers identified two examples of acronyms (2\%), namely ceil, standing for cewek idaman lain or 'the other girl' and coil, standing for cowok idaman lain or 'the other boy/young man'. Interestingly, two examples of the word-formation process 'reverse' $(2 \%)$ were identified, namely the word kera, meaning 'man' and kewec, meaning cewek or 'girl'. The third least frequent word-formation process was diminutive, occurring 7 times (8\%). The examples of diminutive, implying smallness or cuteness, included the words kontil 'penis', konty 'penis', memang 'vagina', memek 'vagina', memy 'vagina', toket 'woman's breast/boob', and ипуии 'cute'.

The top three word-formation processes identified in the data analysis were subsequently blend/clipping compound (41 occurrences, $45 \%$ ), borrowing (29 examples, 31\%), and initialism (10 occurrences, 11\%). Note that the term initialism, as explained previously, refers to words which are formed from the initial letters of several words. 
To display the entire data of the study, the researchers listed alphabetically all of the 92 neologisms collected online in Table 2 below. For the purpose of this paper, only neologisms and their word-formation processes were provided here because the meanings of the neologisms and their relevant explanations will be presented in the following section.

Table 2. Neologisms and word-formation processes

\begin{tabular}{|c|c|c|}
\hline No. & Neologism & Word Formation Process \\
\hline 1 & $3 \mathrm{G}$ & Initialism \\
\hline 2 & 50 (manol) & Blend/clipping compound \\
\hline 3 & ABCDEFG & Initialism \\
\hline 4 & ACDC & Initialism \\
\hline 5 & $\mathrm{AC} / \mathrm{DC}$ & Initialism \\
\hline 6 & $\mathrm{Ag}$ & Initialism \\
\hline 7 & Anjelo & Blend/clipping compound \\
\hline 8 & Bacil & Blend/clipping compound \\
\hline 9 & Bandit & Blend/clipping compound \\
\hline 10 & Bantet & Borrowing \\
\hline 11 & Benong & Borrowing \\
\hline 12 & Berondong & Borrowing \\
\hline 13 & Biatch & Borrowing \\
\hline 14 & Bispak & Blend/clipping compound \\
\hline 15 & Bisyar & Blend/clipping compound \\
\hline 16 & Bohay & Blend/clipping compound \\
\hline 17 & $\mathrm{BRB} !$ & Initialism \\
\hline 18 & Bumil & Blend/clipping compound \\
\hline 19 & Cang benong & Borrowing \\
\hline 20 & Ceil & Acronym \\
\hline 21 & Cengil use & Blend/clipping compound \\
\hline 22 & Cepet & Borrowing \\
\hline 23 & Cewok & Blend/clipping compound \\
\hline 24 & Cibai & Borrowing \\
\hline 25 & Cinere & Borrowing \\
\hline 26 & CocaCola & Blend/clipping compound \\
\hline 27 & Coil & Acronym \\
\hline 28 & Coker & Blend/clipping compound \\
\hline 29 & Cokiber & Blend/clipping compound \\
\hline 30 & Coli & Blend/clipping compound \\
\hline 31 & Dalijo & Blend/clipping compound \\
\hline 32 & Djarum & Initialism \\
\hline 33 & Don juan & Borrowing \\
\hline 34 & Duren & Blend/clipping compound \\
\hline
\end{tabular}




\begin{tabular}{|c|c|c|}
\hline No. & Neologism & Word Formation Process \\
\hline 35 & Duren super & Blend/clipping compound \\
\hline 36 & Eboy & Blend/clipping compound \\
\hline 37 & Frank & Borrowing \\
\hline 38 & Gatheli & Borrowing \\
\hline 39 & GM (ji-em) & Initialism \\
\hline 40 & Gondes & Blend/clipping compound \\
\hline 41 & Handoko & Blend/clipping compound \\
\hline 42 & Henen & Borrowing \\
\hline 43 & Himaho & Blend/clipping compound \\
\hline 44 & Hode & Borrowing \\
\hline 45 & Ipet & Borrowing \\
\hline 46 & Jablay & Blend/clipping compound \\
\hline 47 & Jabrik & Blend/clipping compound \\
\hline 48 & Jambu & Metaphor \\
\hline 49 & Jamu & Blend/clipping compound \\
\hline 50 & Jamu super & Blend/clipping compound \\
\hline 51 & Jancuk & Borrowing \\
\hline 52 & Jens & Borrowing \\
\hline 53 & Jomblowati & Blend/clipping compound \\
\hline 54 & Kencot & Borrowing \\
\hline 55 & Keple & Blend/clipping compound \\
\hline 56 & Kera & Reverse \\
\hline 57 & Kewec & Reverse \\
\hline 58 & Kongat & Borrowing \\
\hline 59 & Kontil & Diminutive \\
\hline 60 & Konty & Diminutive \\
\hline 61 & Lapendos & Blend/clipping compound \\
\hline 62 & Lonte & Borrowing \\
\hline 63 & Maho & Blend/clipping compound \\
\hline 64 & Mahox & Borrowing \\
\hline 65 & Malaga & Blend/clipping compound \\
\hline 66 & Manak & Blend/clipping compound \\
\hline 67 & Manol & Blend/clipping \\
\hline 68 & Memang & Diminutive \\
\hline 69 & Memek & Diminutive \\
\hline 70 & Memy & Diminutive \\
\hline 71 & Menel & Blend/clipping compound \\
\hline 72 & Mokondo & Blend/clipping compound \\
\hline 73 & Ngaceng & Borrowing \\
\hline
\end{tabular}




\begin{tabular}{cll}
\hline No. & Neologism & Word Formation Process \\
\hline 74 & Ngentit & Borrowing \\
\hline 75 & Ngentot & Borrowing \\
76 & Pembalap & Blend/clipping compound \\
\hline 77 & Playboy & Borrowing - English \\
\hline 78 & Purel & Blend/clipping compound \\
\hline 79 & Putol & Blend/clipping compound \\
\hline 80 & Sa`aduni & Borrowing \\
\hline 81 & Semlohe & Borrowing \\
\hline 82 & Senggama & Borrowing \\
\hline 83 & Soteng & Blend/clipping compound \\
\hline 84 & Suzuki & Blend/clipping compound \\
\hline 85 & STW & Initialism \\
\hline 86 & Tilangdarat & Blend/clipping compound \\
\hline 87 & Toket & Diminutive+infixation \\
\hline 88 & Tora sudiro & Blend/clipping compound \\
\hline 89 & Tukmis & Borrowing (Exists in KBBI) \\
\hline 90 & Unyuu & Diminutive \\
\hline 91 & Vankoy & Borrowing \\
\hline 92 & Initialism \\
\hline
\end{tabular}

As displayed in Table 2 above, 41 neologisms were categorized as blends or clipping compounds. Next, to examine the 41 blends or clipping compounds, representing $45 \%$ of the 92 collected neologism samples, the researchers compiled a separate inventory, including the origins and the meanings or referents of the 41 blends or clipping compounds.

Table 3. Blend/clipping compound

\begin{tabular}{clll}
\hline No. & Neologism & Blend/Clipping Compound & Meaning in English \\
\hline 1 & 50 (manol) & lima nol & five nil (nasty girl) \\
\hline 2 & Anjelo & antar jemput lonte & fetch female prostitutes \\
\hline 3 & Bacil & bayur cilik & teenage girl \\
\hline 4 & Bandit & banci genit & flirty transvestite \\
\hline 5 & Bispak & bisa pakai & female prostitute \\
\hline 6 & Bisyar & bisa bayar & female prostitute \\
\hline 7 & Bohay & body aduhay & sexy body \\
\hline 8 & Bumil & ibu hamil & pregnant mother \\
\hline 9 & Cengil use & cewek tengil udiknya selangit & very girl \\
\hline 10 & Cewok & cewek berbentuk cowok & tomboy \\
\hline 11 & Coca Cola & cowok cakep cowok idola & handsome, favourite boyfriend \\
\hline 12 & Coker & cowok keren & cool boyfriend \\
\hline 13 & Cokiber & cowok kita Bersama & our common boyfriend \\
\hline
\end{tabular}




\begin{tabular}{|c|c|c|c|}
\hline No. & Neologism & Blend/Clipping Compound & Meaning in English \\
\hline 14 & Coli & kocok peli & masturbate \\
\hline 15 & Dalijo & dasar peli bejo & simply lucky penis \\
\hline 16 & Duren & duda keren & cool widower \\
\hline 17 & Duren super & duda keren suka perawan & cool widower fond of a virgin \\
\hline 18 & Eboy & (electronic)boy & Playboy \\
\hline 19 & Gondes & gondrong ndeso & male villager with long hair \\
\hline 20 & Handoko & hanya bermodal kontol & only with a penis \\
\hline 21 & Himaho & himpunan mahasiswa homo & $\begin{array}{l}\text { homosexual (male) student } \\
\text { association }\end{array}$ \\
\hline 22 & Jablay & jarang dibelai & female who lacks affection \\
\hline 23 & Jabrik & jarak dibelai karena burik & elderly prostitute \\
\hline 24 & Jamu & janda muda & young widow \\
\hline 25 & Jamu super & janda muda suka perjaka & young widow fond of a single man \\
\hline 26 & Jomblowati & jomblo -wati (suffix) & single female \\
\hline 27 & Keple & kupu-kupu malam, perek, lonte & female prostitute \\
\hline 28 & Lapendos & laki-laki penuh dosa & sinful man \\
\hline 29 & Maho & manusia homo & homo person \\
\hline 30 & Malaga & mabuk lantaran gadis & madly in love with a girl \\
\hline 31 & Manak & manusia nakal & naughty person \\
\hline 32 & Manol & lima nol & five-nil (nasty girl) \\
\hline 33 & Menel & 'memek' gatel & horny girl \\
\hline 34 & Mokondo & modal kontol doang & merely with a penis \\
\hline 35 & Pembalap & pemuda berbadan gelap & dark-skin man \\
\hline 36 & Purel & public relation & female prostitute \\
\hline 37 & Putol & pucuk kontol & penis tip \\
\hline 38 & Soteng & sok ganteng & pretentious handsome \\
\hline 39 & Suzuki & sungguh-zungguh lelaki & real man \\
\hline 40 & Tilangdarat & tinggi langsing dada rata & tall, slim, flat-boobed female \\
\hline 41 & Tora sudiro & toket rata susah dirogoh & tough-to-touch flat boob \\
\hline
\end{tabular}

Interestingly, some of the blends or clipping compounds are derived from English, such as purel (public relation) to refer to a 'female prostitute'. Some are a mixture of languages (Indonesian-English or Indonesian-local language), as in gondes (gondrong or 'long hair' and ndeso 'of a village'), to refer to a male villager with long hair.

\section{The domains of words}

This section presents the answer to the second research question: What social domains are attached to these neologisms? Neologisms found in the virtual world are outcomes of human creativity. It is noteworthy to understand that the new creation of words does not only come from the linguistic perspective but also from a social one. Evans \& Green (2006) highlighted this by 
saying that words are interpreted "with respect to frames or domains of experience" (2006, p. 211). The social understanding of the words helps us to understand the connotations or the association evoked by the word. Some literature has noted how English words are not neutral. Some examples are chairman, fireman, foreman, workman, and spokesman, which have a masculine bias (Sunderland, 2016, p. 36). As the masculine roles are now changing, non-genderspecific alternatives are given, such as chair, firefighter, supervisor, workers, and spokesperson. The change in social outlook and roles demands a new label.

The data show how some gender-specific words can be associated with different associations: emotional (characteristic, personal traits), physical (appearance), sexual (relation to another gender), or financial (related to money) domains. Research has extensively argued that attributes in language can influence judgment and behavior towards groups of people (Banaji et al., 2001). The data show that the neologisms semantically refer not only to men or women, but also to LGBTQ (lesbian, gay, bisexual, transgender, and queer) community. There are 35 new words which semantically refer to man [+adult, +male], 31 of which carry some social attributes. Four words related to the sexual act and body parts are created to avoid the use of literal words which are considered taboo.

Table 4. Neologism referring to men

\begin{tabular}{|c|c|c|}
\hline No & Neologism & Meaning in English \\
\hline 1 & $3 \mathrm{G}$ & strong, handsome, and friendly \\
\hline 2 & $\mathrm{Ag}$ & I am handsome \\
\hline 3 & Berondong & young men \\
\hline 4 & Bokap & father \\
\hline 5 & Cinere & Chinese men \\
\hline 6 & Cocacola & handsome men with fans \\
\hline 7 & Coil & the other lover (male) \\
\hline 8 & Coker & cool men \\
\hline 9 & Cokiber & our common boyfriend \\
\hline 10 & Coli & masturbate \\
\hline 11 & Dalijo & simply lucky penis \\
\hline 12 & Don juan & playboy \\
\hline 13 & Duren & cool widower \\
\hline 14 & Duren super & cool widower fond of a virgin \\
\hline 15 & Eboy & playboy \\
\hline 16 & Frank & weird boy \\
\hline 17 & GM (ji-em) & boy fond of the vagina \\
\hline 18 & Gondes & male villager with long hair \\
\hline 19 & Handoko & only with a penis \\
\hline 20 & Jens & common boy \\
\hline 21 & Kera & men \\
\hline 22 & Kongat & the climax of orgasm in men \\
\hline 23 & Lapendos & sinful man \\
\hline 24 & Lekong & men \\
\hline 25 & Manak & naughty person \\
\hline 26 & Mokondo & merely with a penis \\
\hline 27 & Ngaceng & erection \\
\hline 28 & Pembalap & dark-skin man \\
\hline
\end{tabular}




\begin{tabular}{lll}
\hline 29 & Playboy & playboy \\
\hline 30 & Rangga & men \\
\hline 31 & Soteng & pretentious handsome \\
\hline 32 & Tukmis & men who love seducing others' wives \\
\hline 33 & Vankoy & shabby men \\
\hline 34 & Kontil & Penis \\
\hline 35 & Konty & Penis \\
\hline
\end{tabular}

These words are used in a wide range of contexts with their connotative meanings. Connotative meanings depend on some social factors such as ideology, beliefs, sex, and gender (Chandler, 1995). The meanings of these words carry associations ranging from positive to negative ones. Table 5 shows how these words are associated with positive and negative attributes in different domains, namely: emotional, physical, sexual, and financial attributes.

Table 5. Classification of social attributes

\begin{tabular}{ccccc}
\hline Attribute & Positive & Example & Negative & Example \\
\hline Emotional & 0 & - & 2 & Frank \\
\hline Physical & 9 & $3 \mathrm{G}$ & 4 & Vankoy \\
\hline Sexual & 0 & - & 11 & Tukmis \\
\hline Financial & 0 & - & 2 & Handoko \\
\hline
\end{tabular}

Two words are associated with negative emotional domains. For example, the word frank is defined as diambil dari nama pria Jerman yang artinya aneh 'weird man'. The word lapendos is defined as laki-laki penuh dosa 'a man full of sins'. Some words containing physical attributes are 3G which introduces the concept of Gagah Ganteng Gaul 'strong, handsome, and friendly' and Vankoy which is defined as abang item jelek, kumuh 'black shabby ugly guy'. It is interesting to note that in terms of physical attributes for males, there are more positive connotations than the negative ones. Examples containing sexual attributes are manak which means manusia nakal untuk orang-orang yang nakal, suka grepe-grepe cewenya, meaning 'a bad man who likes to grope his woman', and tukmis which means orang yang suka ngeganggu istri orang or 'a man who loves to seduce someone else's wife'. Negative images are portrayed in all neologisms with sexual references. These neologisms are in line with the stereotypes that men are prone to sin and seduction (Brannon, 2011; Cendra, 2006). Lastly, there are words which contain financial attributes, such as mokondo which refers to istilah yang dipakai orang-orang (pria) yang maunya/bisanya gratisan aja atau cuma modal 'barang' doank or 'guys who love getting stuff for free' and Handoko meaning orang yang tidak bermodalkan apa-apa dan hanya bermodal alat kelamin or 'people who only depend on their genitals'. As men are normally expected to be independent, agentic and goal-oriented (Cuddy et. al, 2010, p. 3), this term is considered degrading to the reference of these words as the society expects men to be financially wealthy.

Table 6 shows 37 neologisms referring to women. Similar to the previous block of words, neologisms referring to women can be further associated with different domains containing positive and negative connotations. 
Table 6. Neologism referring to women

\begin{tabular}{|c|c|c|}
\hline No & Neologism & Meaning in English \\
\hline 1 & 50 (manol) & five nil (nasty girl) \\
\hline 2 & bacil & teenage girl \\
\hline 3 & bantet & sexy \\
\hline 4 & biatch & bitch \\
\hline 5 & brb! & be ready bitch! \\
\hline 6 & bumil & pregnant mother \\
\hline 7 & ceil & the other female lover \\
\hline 8 & cengil use & very girl \\
\hline 9 & cepet & vagina \\
\hline 10 & cewok & tomboy \\
\hline 11 & cibai & vagina \\
\hline 12 & hamdan att & pregnant women \\
\hline 13 & henen & female breast \\
\hline 14 & ipet & vagina \\
\hline 15 & jablay & female who lacks affection \\
\hline 16 & jambu & lovely girlfriend \\
\hline 17 & jamu & young widow \\
\hline 18 & jamu super & young widow fond of a single man \\
\hline 19 & jomblowati & single female \\
\hline 20 & keple & female prostitute \\
\hline 21 & kewec & women \\
\hline 22 & lonte & female prostitute \\
\hline 23 & lontonk & males** \\
\hline 24 & malaga & madly in love with a girl \\
\hline 25 & manol & furious women \\
\hline 26 & memang & vagina \\
\hline 27 & memek & vagina \\
\hline 28 & memy & vagina \\
\hline 29 & menel & horny girl \\
\hline 30 & purel & female prostitute \\
\hline 31 & semlohe & sexy girl \\
\hline 32 & stw & old (middle-aged) woman \\
\hline 33 & tilangdarat & tall, slim, flat-boobed female \\
\hline 34 & toket & breast \\
\hline 35 & tora sudiro & tough-to-touch flat boob \\
\hline 36 & unyu & cute girl \\
\hline 37 & wp & female prostitute \\
\hline
\end{tabular}

These new words are produced creatively through several word-formation processes. However, most gender-specific neologisms have more negative connotations than the positive ones as seen in Table 7. 
Table 7. Social attributes of the neologisms

\begin{tabular}{lcccc}
\hline Attribute & Positive & Example & Negative & Example \\
\hline Emotional & 0 & - & 6 & jablay \\
\hline Physical & 7 & Jambu & 6 & STW \\
\hline Sexual & 0 & - & 7 & purel \\
\hline Financial & 0 & - & 0 & - \\
\hline
\end{tabular}

Table 3 demonstrates that seven words for females contain negative sexual attributes. An example of neologisms containing sexual attributes is the word lonte which means pelacur wanita 'prostitute'. There are four words which are linked to prostitution, such as purel, lonte, wp, and keple. These words suggest that some stereotypes that women are sexual objects remain perceived in society (Royo, et. al 2001; Shifman \& Lemishm, 2009). In terms of physical attributes, there are words containing positive and negative attributes. The word jambu delivers a positive connotation because it means cewe cakep/cantik or a beautiful girl. On the other hand, the word tilangdarat contain negative connotation because it stands for Tinggi Langsing Dada Rata or a woman who is tall and slim but having small breasts. Next, some words convey emotional attributes. These new words link six words with a negative connotation. Some examples are bacil which means bayur cilik, jablay cilik or 'sassy girl' and jablay which means jarang dibelai or 'rarely touched or cuddled'. Unlike neologisms for men, it is interesting to see that there are no words negatively or positively linked to financial attributes.

The creation and meaning of neologisms evolve and change throughout time reflecting the social condition. The emergence of the LGBT community also triggers the creation of new labels. These neologisms correspond not only to male or female, but they also define "other" gender or the LGBTQ community as seen in Table 8.

Table 8. Neologisms for LGBTQ community

\begin{tabular}{lll}
\hline No & Neologism & Meaning in English \\
\hline 1 & ACDC & transgender \\
\hline 2 & AC/DC & transgender \\
\hline 3 & bandit & sassy transgender \\
\hline 4 & benong & transgender \\
\hline 5 & cang benong & transgender \\
\hline 6 & HIMAHO & homosexual students association \\
\hline 7 & hode & transgender \\
\hline 9 & maho & homosexual \\
\hline
\end{tabular}

Table 8 presents nine words corresponding to transgenders and homosexuals. Bieschke et.al. (2007) mention that transgenders are people who express their gender differently from their biological sex, while homosexuals are people who are attracted to the same sex. Homosexuality in Indonesia was considered a part of the society in different regions in Indonesia until Western or Islamic influence (Oetomo, 2001). Boelstroff (2005) documented that homosexuality has emerged for at least a thousand years. The practice can be traced back to local rituals and traditions. The existence of Bissu in South Sulawesi, Warog in Reog Pnorogo, and Rateb Sadati in Aceh are related to homosexuality (Boelstroff, 2005; Adihartono, 2013). This social reality can be extended to the use of language. The words ACDC and AC/DC are metaphorically taken from 
electric current are synonymous with bencong or transgender. Himaho, maho and mahox refer to gays. Neologisms referring to LGBT are not expanded further to emotional, sexual, and physical domains as the use of these words in reference to particular groups straightforwardly evokes negative stigma in the society. These terms show how the existence of LGBT is still challenged in the Indonesian context.

\section{CONCLUSION}

This study categorized the word-formation processes of gender marked neologisms, consisting of 92 data samples, into seven word-formation processes, starting from the least up to the most frequent processes, namely metaphor, reverse, acronym, diminutive, initialism, borrowing and blend/clipping compound. The results also showed that blends or clipping compounds were formed from English, Indonesian, and local languages, as in the English-Indonesian bohay ('body' and aduhay 'sexy') to refer to a 'sexy female body'. These new words are semantically associated with different social domains: emotional, financial, physical, sexual, and financial ones. The most dominant domain attached to both male-specific and female-specific neologisms is the physical domain, mostly positive. Meanwhile, neologisms which are related to sexual domains are used in negative connotation for both males and females. Interestingly, neologisms referring to LGBT are not expanded further to emotional, sexual, and physical domains as the use of these words in reference to particular groups straightforwardly evokes negative stigma in the society. Although this study has its limitations, it argues that although some words are used to empower particular gender, many words are used to expand sexual stereotypes. Instead of serving as an act of empowerment, some neologisms reflect negative stigma to males, females and LGBTQ.

\section{Note}

The authors would like to thank the anonymous reviewers for their very helpful comments on the earlier draft of the paper.

\section{REFERENCES}

Adihartono, W. (2015). Homosexuality in Indonesia: Banality, prohibition and migration (The case of Indonesian gays). International Journal of Indonesian Studies, 1(2), 1-15.

Akunna, O. (2012). Social media neologisms: A morpho-semantic analysis. Unpublished thesis: University of Lagos, Akoka.

Banaji, M. R., Lemm, K. M., \& Carpenter, S. J. (2001). The social unconscious. In M. Hewstone \& M. Brewer (Series Eds.) \& A. Tesser \& N. Schwartz (Vol. Eds.), Blackwell handbook of social psychology: Vol. 1. Intraindividual processes (pp. 134-158). Oxford: Blackwell.

Bennett, S. (2012). All twitter. http://www.mediabistro.com/alltwitter/twittertopcountries_b26726

Bieschke, K.J., Perez, R.M. \& DeBord, K.A. (2007). Handbook of counseling and psychotherapy with lesbian, gay, bisexual, and transgender clients. Washington, DC: American Psychological Association. 
Boellstorff, T. (2005). The gay archipelago: Sexuality and nation in Indonesia. Oxford: Princeton University Press.

Bram, B. (2011). Major total conversion in English: The question of directionality. Unpublished dissertation: Victoria University of Wellington.

Brannon, L. (2011). Gender: Psychological perspectives (Sixth edition). London: Pearson.

Cendra, A. (2016). A linguistic analysis of verbal humour found in BBC Radio Drama Series Cabin Pressure: Abu Dhabi. Undergraduate thesis. Yogyakarta: Sanata Dharma University.

Chandler, D. (1995). Semiotics for beginners. Online version. http://visualmemory.co.uk/daniel/Documents/S4B/sem06.html Cobley, P. \& Jansz, L. (1999). Introducing semiotics. Cambridge: Icon Books Ltd.

Cuddy, A.J.C, Crotty, S., Chong, J. \& Norton, M.I. (2010). Men as cultural ideals: How culture shapes gender stereotypes. Working Paper. http://www.hbs.edu/faculty/Pages/item.aspx?num=37849.

Evans, V. \& Green, M. (2006). Cognitive linguistics: An introduction. Edinburgh: Edinburgh University Press.

Fansuri, Y. (2006). Word formation process of neologism found in cosmopolitan. Unpublished undergraduate thesis. Surabaya: Universitas Kristen Petra.

Folse, K.S. \& Vitanova, G. (2006). Sociolinguistic factors in TESOL: The least teachers and teacher educators should know. TESL Reporter 39, 1 (2006), 48-58.

Holmes, J. (2008). Introduction to sociolinguistics. London: Routledge.

Litosseliti, L. (2006). Gender and language: Theory and practice. London: Hodder Arnold

Martin, N. (2018). Apa kata ahli linguistik soal 'pelakor'. https://theconversation.com/apa-kataahli-linguistik-soal-pelakor-92288

Martin, N. (2019). Code-switching or bahasa gado-gado in discussion of homosexuality in Indonesian films. Journal of Homosexuality, 0(0), 1-23. DOI: 10.1080/00918369.2019.1601436

Meehan, K.S. (2013). Gender variant neologisms. sdsudspace.calstate.edu/bitstream/handle/10211.10/4199/Meehan_Kelly.pdf

Melissa, E., Hamidati, A., Saraswati, M.S. \& Flor, A. (2015). The internet and Indonesian women entrepreneurs: Examining the impact of social media on women empowerment. In Impact of Information Society Research in the Global South (pp. 203-222). Singapore: Springer.

Mikić, J., Mrčela, A.K. \& Golob. M.K. (2018). Gendered and 'agreed' language and power inequalities: An intersectional approach. Gender a výzkum/Gender and research, 19(2), 3254.

Ming-chang, L. (2013). A new perspective on the creation of neologisms. Acta Linguistica Asiatica, 3(1), 47-59.

Mustofa, M. (2009). Neologi dalam bahasa Arab: Kajian morfologis, sintaksis dan semantik terhadap istilah komputer dan internet dalam bahasa Arab Modern. Unpublished thesis. Yogyakarta: Universitas Gadjah Mada.

Nakamura, M. (2002). The dynamic model of language and gender. Shizen, Ningen, Shakai, 32 , $1-26$. 
Newmark, P. (1988). A textbook of translation. London: Prentice.

Oetomo, D. (2001). Memberi suara pada yang bisu. Surabaya: Galang Press.

Pasaribu, T.A. (2017). Gender differences and the use of metadiscourse markers in writing essays. International Journal of Humanity Studies (IJHS), 1(1), 93-102.

Pasaribu, T.A. \& Kadarisman, A.E. (2016). Coding logical mechanism and stereotyping in gender cyber humors. Celt: A Journal of Culture, English Language Teaching \& Literature, 16(1), 22-48. https://doi.org/10.24167/celt.v16i1.485.

Royo, M., Aldás, J., Küster, I. \& Vila, N. (2001). Sexism and gender role portrayals in Spanish TV commercials. http://www.researchgate.net/profile/Ines_Kuester_Boluda/publication.

Shifman, L. \& Lemish, D. (2009). Between feminism and fun(ny)nism. Information, Communication \& Society, 13(6), 870-891. DOI:10.1080/13691180903490560

SocialBakers. (2012). Indonesia http://www.socialbakers.com/facebookstatistics/indonesia.

Sunderland, J. (2016). Language and gender: An advanced resource book. London: Routledge.

Syuhada, A.A. \& Gambetta, W. (2013). Online marketplace for Indonesian micro small and medium enterprises based on social media. Procedia Technology, 11, 446-454.

Tannen, D. (1994). Talking from 9 to 5: Women and men in the workplace. London: Virago Press.

Victoria F., Rodman, R. \& Hyams, N.M. (2003). An introduction to language. Boston: Thomson/Heinle.

Wijana, I.D.P. (2012). The use of English in Indonesian adolescent's slang. https://journal.ugm.ac.id/jurnal-humaniora/article/view/1373

Yule, G. (2010). The study of language. Cambridge: Cambridge University Press. 